\title{
Determination of Trace Metals and Depositional Environment of Organic Matter from Oil Sands, Ondo, SW Nigeria
}

\author{
A. Uzoegbu M. Uche ${ }^{1}$ Ndukwe V. Azubuike ${ }^{2}$ \\ ${ }^{I}$ Department of Geology, College of Physical and Applied Sciences, Michael Okpara University of Agriculture, \\ Umudike, \\ ${ }^{2}$ Department of Geology, Faculty of Sciences, University of Port Harcourt,
}

\begin{abstract}
The oil sands are majorly deposited in the Western Nigeria spans a distance of about 120km, the tar deposits occurring as heavy oil and manifest as seepages and at near surface or at the surface as impregnated sediments at road cuts, cliff faces and river banks and at break of slopes. Samples were collected at Agbabu, Ilubinrin and Loda where open mining is at progress. The asphaltene content was determined and the concentration of a suite of metals mainly the biophiles were determined. The objective of this study is to determine the genetic relationship of these exposed tar sand and seeps based on the fact that Asphaltene have been redefined as micro kerogens bearing in preserved state the features of the original input organic matter. The result indicates that sample obtained from the drilled wellbore (A1) showed an outstanding difference from others. The seep samples (A2, A3, A4, and A6) irrespective of locations showed close relations as represented by the ternary plots. Samples with significant sand content (5.7) also showed similarity. It is suggested that since samples (A2, A3, A4, and A6) were seeps, they could have migrated via structural permeability e.g. faults and fractures while samples 5, 7 could have migrated via pore network in the trapless reservoir sandbody. The \%Asphaltene versus Co/Ni ratio groups the samples into tarsands and tar/heavy oil seeps. CPI varies from 0.24 to 1.00 in IREN and 0.16 to 4.13 in LODA showing that LODA attended higher level of maturation as compared to IREN. Pr/Ph ratio (0.78-3.31; 0.87-2.33), Long/Short ratio (0.72-0.77; 1.00-1.60), OEP (0.02-0.68; 0.33$0.42), P r / n-C_{17}(0.84-2.25 ; 0.19-1.61), P h / n-C_{18}(0.04-3.73 ; 1.00-1.67)$ and $C_{31} /\left(C_{31}+C_{29}\right)(1.00-3.40 ; 1.20-3.60)$ revealed contributions of marine to terrestrially source of organic matter and dysoxic to marine as depositional environment.
\end{abstract}

Index Terms: Depositional environment, Petroleum geochemistry, Source, Tarsand, Trace metals.

\section{Introduction}

Oil sands are sedimentary rocks that contain bitumen or heavy oil, and are also known as tar sands or asphaltic sands. Oil sand bitumen and/or heavy oil are formed by low temperature alteration of crude oil, by biodegradation, water washing or light-hydrocarbon volatilization, thus resulting in concentration of high molecular weight hydrocarbons and heteroatomic compounds of resins and asphaltenes. Oil sand often exists at the edge, and within shallow layers of a basin, and may be exposed at the surface by tectonic uplift

The hydrocarbon mixtures found in northern Alberta have historically been referred to as tar, pitch or asphalt. However, oil sands are now used most often to describe the naturally occurring bitumen deposits. This helps distinguish it from the other terms, which are associated with distilled or man-made products, such as the mixtures used to pave roads.

Oil sands are a more accurate term because bitumen is a substance that contains oily sand. The resource is composed of three main elements: sand, water and bitumen. Regardless of the name, oil sands and tar sands describe the same thing. Due to the nature of developing the oil sands, industry faces significant challenges to reduce the amount of greenhouse gas (GHG) emissions, water and natural gas required to create a barrel of refined oil. It takes more effort to produce heavy oils, including oil from the oil sands, than conventional oil. But new technologies are reducing the footprint of oil sands development.

Oil sand deposits originates from conventional hydrocarbon sources, when organic matter in the source rock is matured, the rock matrix starts to generate oil, the oil generated is expelled and eventually commences primary migration. After which it finds its way into a carrier bed and commences secondary migration. It could get into a trap which provides the configuration on which the accumulation sits and grows. However, where the trap was not in place as at the time of emplacement of the oil in the reservoir, the migrating oil will migrate out most possible into the surfaces where its known as seeps. Figure 1 shows an idealized foreland basin petroleum system, it also shows the reservoir grading into shallow depth where the oil migrates to and remains exposed to oxidation and biodegradation with increasing loss of lighter molecular weight ends of the hydrocarbon, the heavier ends are left behind which remains rich in asphaltene. Most petroleum and petroleum related resources like bitumen contain trace metals as an integral part of their content. Trace metals in petroleum and related resources have concentrations in the range of $100 \mu \mathrm{g} / \mathrm{g}$ to $1 \mathrm{ng} / \mathrm{g}$. The origin of trace metals in oils could be 
explained by the fact that they could be incorporated into the organic matrix during diagenesis of the original biological material, it could also be from the abstraction from aqueous phase. The amount in petroleum reflects the nature of the source materials, the processes of migration, maturation and alteration may modify the inherent distribution of metals but not significantly as stated by [1]. Nickel and

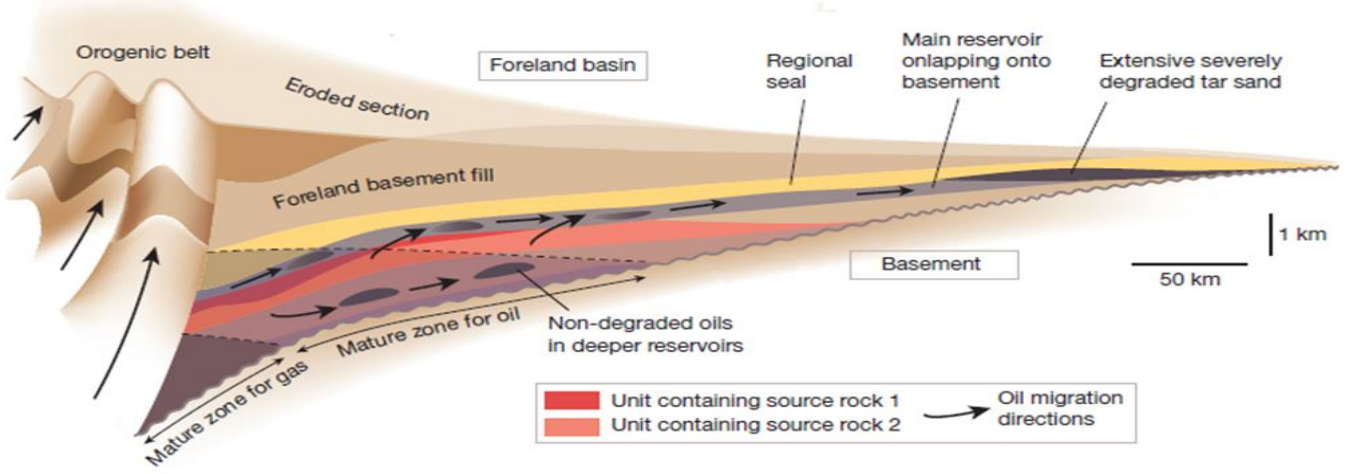

Fig. 1: An idealized foreland basin petroleum system, showing oil migrating into more shallow depths where there is no effective seals and it become biodegraded and exists as oil sands [2].

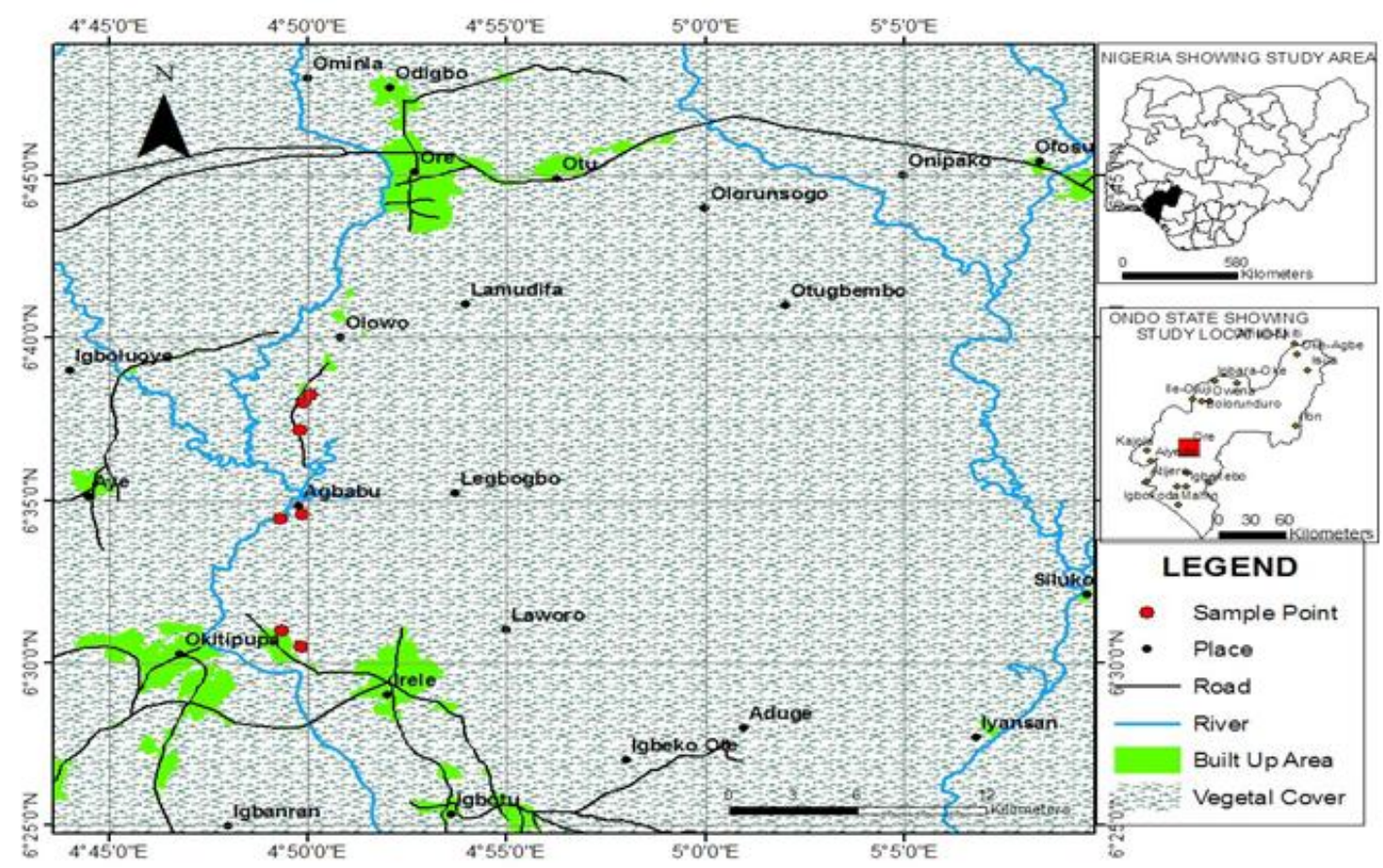

Fig. 2: A physiographic map showing location of sample collections [3].

vanadium are the most abundant metals; others that could be found are silicon, iron, aluminum, calcium, magnesium, copper, lead, tin, arsenic, antimony, zinc, silver, chromium and molybdenum. Studies has revealed that the most degraded oil has higher abundance metals, this may be attributed to the fact that the lighter fraction that is lost due to various processes, if presence will cause the metals concentration to be lower than normal. The aim of this research work is to determine the trace metals, source and environment of deposition of the organic matter from the oil sands.

\section{Geologic Setting}

The study area lies within latitude $06^{\circ} 38^{\prime}-06^{\circ} 40^{\prime} \mathrm{N}$ and longitude $04^{\circ} 34^{\prime} \mathrm{E}-04^{\circ} 37^{\prime} \mathrm{E}$, and falls within the eastern Dahomey Basin (Fig. 4). Samples for this study were obtained from five different locations where there are outcrops of the tarsands and where there exist live seepage from the tar sand. Samples were obtained from Agbabu, Ilubinrin and roads along Irene and Loda all around Ore Ondo State shown in figure 4. Agbabu is well known as a place were open pit mining of Nigerian tar sand deposit occurs. 
[4], has highlighted origin/occurrence of tar sand deposit in Nigeria, this subject has several schools of thought since its discovery. One of these suggests that petroleum hydrocarbon could have migrated from Niger Delta Basin via fractures, faults or extensive and interconnected sand bodies into Eastern portion of the Dahomey Basin. The stratigraphy of the Dahomey basin is shown in Fig. 5. The formations of interest from the oldest to the youngest are Ise, Afowo and Araromi formation. Ise formation unconformably overlies the basement complex of South Western Nigeria, consisting of conglomerates and grits at the base which is in turn overlain by coarse to medium grained sands with interbeded kaolinite. An age range of Neocomian-Albian is assigned to this formation based on paleontological assemblages. Afowo formation overlies the Ise formation, and composed of coarse to medium grained sandstone with variable but thick interbedded shale, siltstone and claystone. The sandy facies are tar bearing while shales are organic-rich. Using palynological assemblage, a Turonian age is assigned to the lower part of this formation, while the upper part ranges into Maastrichtian [5].

\begin{tabular}{|c|c|c|c|c|c|}
\hline $\begin{array}{l}\text { Generalized } \\
\text { Lithology }\end{array}$ & Formation & & Age & $\begin{array}{c}\text { Thickness } \\
\text { (feet) }\end{array}$ & Comments \\
\hline & $\begin{array}{l}\text { Benin Fm., } \\
\text { Coastal Plains } \\
\text { Sands }\end{array}$ & \multirow{3}{*}{ 홀 } & $\begin{array}{c}\text { Pleistocene - } \\
\text { Oligocene }\end{array}$ & $\begin{array}{c}0- \\
1600\end{array}$ & coastal-plain clastics \\
\hline & $\begin{array}{c}\text { Oshosun - llaro - } \\
\text { Ameki Fms. }\end{array}$ & & Eocene & $\begin{array}{l}200- \\
1000\end{array}$ & $\begin{array}{l}\text { fluvial and marine } \\
\text { sands and clays }\end{array}$ \\
\hline & Ewekoro Fm. & & Paleocene & $\begin{array}{l}400- \\
1000\end{array}$ & $\begin{array}{l}\text { marine shale. } \\
\text { limestone }\end{array}$ \\
\hline & $\begin{array}{l}\text { Araromi Fm. } \\
\text { Abeokuta Fm. }\end{array}$ & \multirow{3}{*}{ क्षे } & Maastrichtian & $\begin{array}{l}500- \\
1000\end{array}$ & $\begin{array}{c}\text { coastal sand, shale; } \\
\text { marine shale }\end{array}$ \\
\hline & $\begin{array}{l}\text { Afowo Fm. } \\
\text { Turonian Sst. } \\
\text { Albian Sst. }\end{array}$ & & $\begin{array}{c}\text { Campanian - } \\
\text { Aptian }\end{array}$ & $\begin{array}{l}0- \\
800\end{array}$ & $\begin{array}{l}\text { marine sandstone, } \\
\text { shale, limestone }\end{array}$ \\
\hline & Ise Fm. & & $\begin{array}{l}\text { Barremian - } \\
\text { Neocomian }\end{array}$ & $\underset{6000+}{0-}$ & $\begin{array}{l}\text { continental and } \\
\text { lacustrine rift-basin fill }\end{array}$ \\
\hline & $\begin{array}{c}\text { crystalline } \\
\text { basement } \\
\text { (undifferentiated) }\end{array}$ & \multicolumn{2}{|c|}{$\begin{array}{l}\text { Cambrian - } \\
\text { Precambrian }\end{array}$} & & $\begin{array}{l}\text { metamorphic and } \\
\text { igneous complex }\end{array}$ \\
\hline
\end{tabular}

Fig. 3: Stratigraphic Column of the Eastern Dahomey Basin [6].

\section{Materials And Methods}

Samples for this research bear live tars flowing from the sand as shown in figure 4, in such case live samples collected were pure tars/heavy oil. The tarsand were drilled with hand augar to about $1 \mathrm{ft}$ for samples, the samples were store in sample bags and properly labeled. The live seeps were carefully scooped and stored in a sample bottle and carefully labeled The distance of sample locations from each other was also recorded (Figure 2), Location A1 to A2 is about $1 \mathrm{~km}$, location A2 to A3 is $2.3 \mathrm{~km}$, location A3 to A4 is $50 \mathrm{~m}$, location A4 to 5 is $700 \mathrm{~m}$, location 5 to A6 about $11 \mathrm{~km}$ while location A6 to 7 is $800 \mathrm{~km}$ The tarsand $(5 \mathrm{gms})$ were first dissolved in DCM (dichloromethane) (200mls) to remove the sand, clay which are insoluble in DCM, the solution was decantated separating the sand and clay out. The resultant solution was left in a fume chamber to evaporate, the tar was then dissolve in $200 \mathrm{mls}$ of pentane (AnalaR Grade) while stirring and continued for $1 \mathrm{hr}$. the solution was allowed cool in a freezer for $2 \mathrm{hrs}$ at $5^{\circ} \mathrm{C}$. The precipitated asphaltene were filtered off washed with cold n-pentane and dried in a dessicators, then weighed and scraped of into a sample vials. The obtained asphaltene were then presented for AAS analysis for a suite of metals. The metals were mainly the biophiles [7].

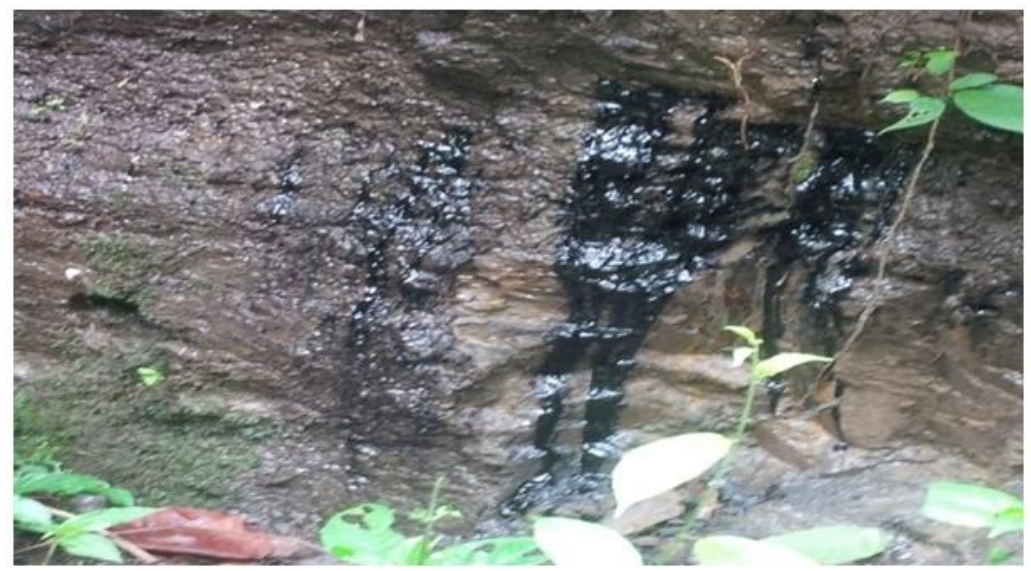

Fig. 4: Showing a live seep from the outcrop oil sand at Agbabu 
The analytical method employed is the AAS (Atomic Absorption Spectrophotometry), this is a method for the analysis of trace metals in samples. The principle behind this equipment is the Beer-Lamberts law. The concept is that the concentration of the metals can be calculated using the Beer-Lambert law.The data generated in this research project was treated and analyzed as a $100 \%$ stack plot, which enable the recognition at a glance, the distribution of the suite of analyzed metals. The will enable delineating similarities of the tarsand and how genetically related they are. The data will also be represented as ternary plot (triangular cross plots), this mode of presentation has been recognized as one of the reliable statistical techniques for data treatment and presentations. This method will also help delineate samples that constitute genetic families.

\section{Result And Discussions}

The results of the AAS analysis (Table 1), show that samples A3 and 5 has the highest concentrations of metals, while sample A1has the lowest concentration of metals. Table 2 shows the asphaltene content of the different samples, samples 5 and 7 has the lowest percentage composition of asphaltene of 5\% each while sample A1 has the highest content of $37.5 \%$. Percentage composition of asphaltene ranges from $37.5 \%$ to $5 \%$.

Table 1: Trace metal concentrations in the various asphaltene samples.

\begin{tabular}{|l|l|l|l|}
\hline Sample & Cobalt & Nickel & Zinc \\
\hline A2 & 443.57 & 113.57 & 70.64 \\
\hline A3 & $6,595.64$ & 312.08 & 619.80 \\
\hline 7 & 353.06 & 86.86 & 272.23 \\
\hline 5 & $4,427.96$ & 740.67 & $2,945.20$ \\
\hline A4 & 365.68 & 67.97 & 31.34 \\
\hline A1 & 37.38 & 33.08 & 6.48 \\
\hline A6 & 351.76 & 92.46 & 39.12 \\
\hline
\end{tabular}

Table 2: Amount of asphaltene present in various tarsand samples.

\begin{tabular}{|l|l|l|l|l|}
\hline S/N & Sample & Sample & Asphaltene & Asphaltene \\
\hline & Name & Weight $(\mathbf{g})$ & Weight $(\mathbf{g})$ & $(\%)$ \\
\hline 1 & A1 & 4.00 & 1.50 & 37.50 \\
\hline 2 & A2 & 2.00 & 0.60 & 30.00 \\
\hline 3 & A3 & 2.10 & 0.45 & 21.40 \\
\hline 4 & A4 & 2.05 & 0.50 & 24.40 \\
\hline 5 & 5 & 2.00 & 0.10 & 5.00 \\
\hline 6 & A6 & 2.02 & 0.65 & 32.20 \\
\hline 7 & 7 & 2.00 & 0.10 & 5.00 \\
\hline
\end{tabular}

\section{Trace Metal Distribution}

The correlation study of the samples based on trace metals and the asphaltene content indicates that the samples are related and can be grouped into genetic families. Asphaltenes have been redefined as micro kerogens bearing in preserved state the features of the original source of organic matter [8]-[9], since the trace metals content was determined from the asphaltene, the established relationships should be a true representation that exists. Figure 3 is a plot of $\mathrm{Co} / \mathrm{Ni}$ ratio and that of \%Asphaltene, the plots discriminates the samples into different genetic families. Family A consist of samples 5 and 7 and are basically the samples that were obtained as tarsand, with a significant amount of sand. While family B are samples that were obtained as seeps of tar or heavy oils. Sample A1 is a live sample that was obtained from the wellbore. The plot distinguishes tarsands from live tars/heavy oils. Figure 4 is a ternary plot using Ni, Co and $\mathrm{Zn}$. The ternary plot also discriminates the samples into genetic families. Corroborating the genetic relationships with their corresponding sample site, it is observed that all samples the ware obtained as tarsand (samples 5 and 7) represents samples which migrated via networks of pores embedded in the matrix of the sandstone reservoir. Samples that were obtained as seeps (A2, A3, A4, and A6) represent those that migrated via fractures and faults. Sample A1 is outstanding because it was obtained from a well bore that was drilled into the formation bearing the tar/heavy oil.

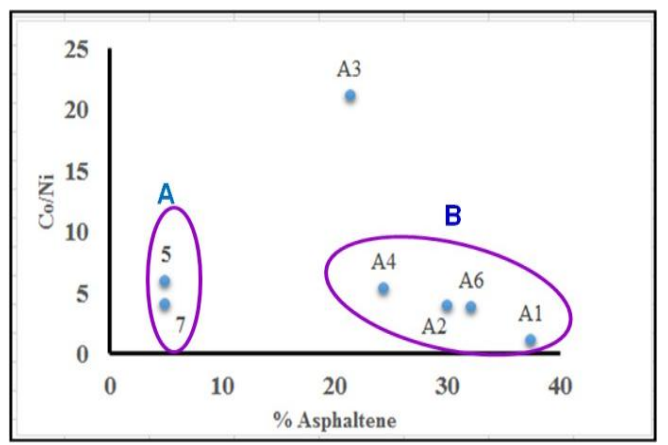

Figure 3: Graph of \%asphaltene and $\mathrm{Co} / \mathrm{Ni}$ ratio, grouping the samples into families. 


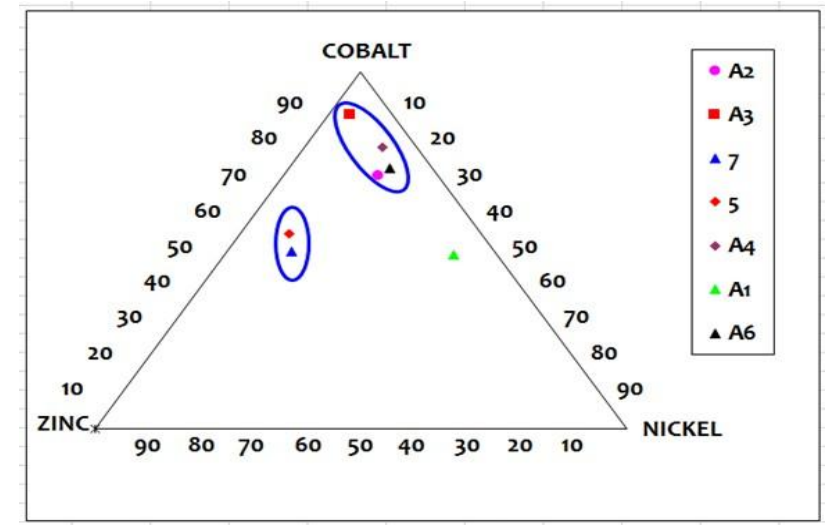

Figure 4: The ternary plot of the biophile metals showing clusters of samples.

\section{Depositional Environment}

Predominantly, lower molecular weight $n$-alkanes exist in fresh oil while higher plants, marine animals and sedimentary bacteria show higher molecular weight n-alkanes [10]. Main peaks with carbon numbers greater than $\mathrm{nC}_{20}$ reflect the significant incorporation of higher plant wax and some fungi, whereas those with lower carbon numbers indicate major inputs from microbial activity (algae and bacteria $-\mathrm{nC}_{17}, \mathrm{nC}_{18}$ ) or petroleum (diesel exhaust $-\mathrm{nC}_{20}, \mathrm{nC}_{21}$ ). LMW/HMW ratio in $\mathrm{n}$-alkanes in sediments is used to distinguish macrophytes from terrestrial plants [10]. Values below 1 show natural input from terrestrial biogenic sources while values above 1 show natural input from marine biogenic sources. LMW is predominance in the sample locations.

Low Long Chain Hydrocarbons (LHC)/ Short Chain Hydrocarbons (SHC) values such as 0.21 to 0.80 are dominantly phytoplankton derived. Intermediate values such as 2.38 to 4.33 show a mixture of both input sources. Higher ratios above 4.0 are dominated by terrestrial plant waxes [10]. It is predominance of long chain over short chain $\mathrm{n}$-alkanes as their values varies from 0.54 to 1.60 with a mean of 0.89 (Table 2) indicating a dominance source of marine organic matter [11]. The $\mathrm{Pr} / \mathrm{Ph}$ ratios from 0.78 to 3.31 with value of 1.58 in all localities suggest a marine to terrestrial derived material because $\mathrm{Pr} / \mathrm{Ph}$ is found mainly from the phytol portion of photosynthetic plant chlorophyll [12]-[13]. Value of OEP varies from 0.02 to 0.68 with mean of 0.36 (Table 3 ). These values of OEP for immature higher plant contributions are often $>1.0$ but approach 1.0 with increasing maturity [12], [14]. The CPI results gotten from tar sand could be said that majority of the terrestrial material is probably transported by fluvial processes and deposited under marginal to marine environments [15]-[16] which contribute to the marine source of OM in the Ondo samples.

Table 3: Showing n-Alkanes, Isoprenoids distribution and ratios from GC of tar sand samples from Ondo, Dahomey Basin.

\begin{tabular}{|c|c|c|c|c|c|c|c|c|c|c|}
\hline Sample & Locality & Lithology & Basin & CPI & $\mathrm{Pr} / \mathrm{Ph}$ & Long/Short & OEP & $\mathrm{Pr} /$ & $\mathrm{Ph} /$ & C31/ \\
\hline Name & & & & & Ratio & Ratio & & $\mathrm{n}-\mathrm{C1} 7$ & n-C18 & $(\mathrm{C} 31+\mathrm{C} 29)$ \\
\hline AGBA-01 & Agbagu & Tarsand & Dahomey & 2.12 & nd & 0.72 & 0.68 & 0.84 & nd & 1.00 \\
\hline $\mathrm{AGBA} \cdot 02$ & $"$ & $"$ & " & 1.25 & 1.13 & 0.77 & 0.02 & 1.50 & 1.60 & 1.10 \\
\hline ILUB-01 & Illubinrin & " & $"$ & 1.85 & 0.87 & 0.82 & 0.41 & 2.25 & 1.00 & 3.40 \\
\hline REE-01 & Irele Road & " & " & 2.11 & 0.78 & 1.60 & 0.41 & 0.19 & 1.67 & 3.30 \\
\hline IREN-02 & $"$ & " & $"$ & 0.24 & 1.09 & 0.54 & 0.57 & 0.75 & 3.73 & 1.00 \\
\hline IREN-03 & $"$ & $"$ & $"$ & 1.00 & 3.31 & 0.98 & 0.06 & 1.61 & 0.80 & 1.20 \\
\hline LODA-01 & Loda Road & $"$ & " & 4.13 & 2.33 & 1.00 & 0.42 & 0.10 & 0.04 & 3.60 \\
\hline LODA-02 & " & " & " & 0.16 & nd & 0.66 & 0.33 & 0.87 & nd & 1.00 \\
\hline & & $\begin{array}{l}\text { nd }=\text { Not } \\
\text { determine }\end{array}$ & & & & & & & & \\
\hline
\end{tabular}

The ratio of $\mathrm{C}_{31} / \mathrm{C}_{31}+\mathrm{C}_{29}$ varies from 1.00 and 3.60 with mean value of 1.95 (Table 3). The carbon preference index (CPI) of the n-alkanes also varies with values ranging from 0.14-0.90in the oil sand samples from MBB- 0.1 and 0.01-3.80 in the oil samples from MBA-02. This indicates more maturation of OM in MBB area than the MBA area or location MBB may be closer to higher heat source. The CPI $25-33=0.5 *\left[\left(\mathrm{C}_{25}-\mathrm{C}_{33}\right) /\right.$ 
$\left.\left(\mathrm{C}_{24}-\mathrm{C}_{32}\right)\right]+\left[\left(\mathrm{C}_{25^{-}} \mathrm{C}_{33}\right) /\left(\mathrm{C}_{26}-\mathrm{C}_{34}\right)\right]$ n-alkanes can be derived from two sources i.e. vascular plant wax and fossil fuel combustion products [17]. An odd carbon preference is characteristic of oils derived from source rocks deposited in non-marine environments. In contrast, the predominance of an even numbered n-alkane preference is commonly observed in bitumen and oils derived from carbonate or evaporate rocks. This is usually characterized with CPI values that are lower than 1 . If the total even and odd numbers of paraffin are equally abundant, the value of (CPI) will be equal to 1 as generally observed in high maturity samples. This shows that the hydrocarbons are petrogenic in origin [17].

Predominance of vascular plants input to the environment usually demonstrates CPI values from1 to 3 [17]. The average CPI value of 1.61 was obtained from Ondo samples which varies 0.16 to 4.13 suggesting marginal maturity. CPI in the $\mathrm{C}_{25}-\mathrm{C}_{31}$ range of samples from the Dahomey Basin is generally high (> 1), indicating immaturity and reflecting the contribution of wax-derived n-alkanes which form bitumen at the end of diagenesis [18]-[23].Pr/ $\mathrm{C}_{17}$ values range from 0.10-2.25 while $\mathrm{Ph} / \mathrm{C}_{18}$ is between 0.04-3.73 (Table 2; Fig. 4), these values indicate marginal to marine depositional environment. The result of $\mathrm{C}_{31} /\left(\mathrm{C}_{31}+\mathrm{C}_{29}\right)(1.00-3.60)$ also supported values obtained for $\mathrm{Pr} / \mathrm{C}_{17}$ and $\mathrm{Ph} / \mathrm{C}_{18}$ depositional environment of the organic matter as dysoxic to marine environment [10].

\section{References}

[1]. $\quad$ A. J. G. Barwise, "Role of Nickel and Vanadium in Petroleum Classification. Energyand.” Fuels. vol. 4, p. 647 - 652, 1990.

[2]. I. M. Head, D. M. Jones and S. R. Larter, "Biological Activity in the Deep Subsurface and the Origin of Heavy Oil." Nature, vol. 426, p. 344-352, 2003.

[3]. [3] V. A. Ndukwe, B. O. Ogunyinka and S. Abrakasa, (2015), "Some Aspects of the Petroleum Geochemistry of Tarsand Deposits in Western Nigeria." Pyrex J. Geol. Min. Res., vol. 1, p. 1-6, 2015.

[4]. A. I. Akintola., P. R. Ikhane and O. Adeola, "Heavy mineral and grain size characterization of bitumen seeps exposed at Ogbere, South Western. Nigeria." Int. Res. J. Geol. Min., vol. 3 no. 2, p. 82-101, 2013.

[5]. A. A. Akinmosin, K. O. Omosanya, P. R. Ikhane, G. O. Mosuro and I. Goodluck, "Characterisation of a bitumen seepage at Onikitibi, Eastern Dahomey Basin, SW, Nigeria.” Adv. Applied Sci. Res., vol. 3 no. 4, p. 2078-2089, 2012.

[6]. L. P. Akinyemi, R. K. Odunaike and O. O. Fasunwon, "Physical and chemical characterization of oil sands observed at Imeri in Ogun state of South Western Nigeria," CSPG/CSEG/CWLS GeoConvention Integration, Geoscience Engineering Partnership, 6-12 May, 2013, Calgary, Ab, Canada.

[7]. O. T. Udoh, S. Ekwere and S. Abrakasa, "Some trace metals in selected Niger Delta crude oils: Application in oil-oil correlation studies." J. Min. Geol., vol. 28, p. 289-292, 1992.

[8]. B. Tissot, B. Durand, J. Espitalie and A. Combaz, "Influence of Nature and Diagenesis of Organic Matter in Formation of Petroleum.” Amer. Assoc. Petrol. Geol. Bull., vol. 58, p. 499-506, 1984.

[9]. R. Pelet, F. Béhar and J. C. Monin, "Resins and asphaltenes in the generation and migration of petroleum." Org. Geochem., vol. 10 nos.1-3, p. 481-498, 1986

[10]. S. Pingchang, L. Zhaojun, G. Reinhard, X. Yinbo, L. Rong, L. Baoyi, M. Qingtao and X. Jinjun, "Oil Yield and Bulk Geochemical Parameters of Oil Shales from the Songliao andHuadian Basins, China: A Grade Classification Approach.” Oil Shale, vol. 30 no.3, p. 402-418, 2013.

[11]. Z. Guangyou, W. Zhengjun and S. Jin, "Geochemical Characteristics of High quality Hydrocarbon Source Rocks in the Nanpu Sag of the Bohai Bay Basin, China." Oil Shale, vol. 30 no.2, p. 117-135, 2013.

[12]. B. M. Didyk, B. R. T. Simoneit, S. C. Brassell and G. Eglinton, "Organic geochemical indicators of paleodepositional conditions of sedimentation." Nature, p. 272, 216-222, 1978.

[13]. H. A. Illich," Pristane, phytane and lower molecular weight isoprenoid distributions in oils." Amer. Assoc. Petrol. Geol., Bull., vol. 67, p. 3385-393, 1983.

[14]. E. E. Bray and E. D. Evans, "Distribution of n- paraffins as a clue to recognition of source beds." Geochem. Cosmochim. Acta, vol. 22, p. 2-15, 1961.

[15]. M. I. Bird, R. E. Summons, M. K. Gagan, Z. Roksandic, L. Dowling, J. Head, L. K. Fifield, R. G. Cresswell and D. P. Johnson, "Terrestrial vegetation change inferred from n-alkanes $13 \mathrm{C}$ analysis in the marine environment." Geochem. Cosmochim. Acta., vol. 59, p. 2853-2857, 1995.

[16]. N. G. Obaje, H. Wehner, G. Scheeder, M. B. Abubakar and A. Jauro, "Hydrocarbon prospectivity of Nigeria's inland basins: From the viewpoint of organic geochemistry and organic petrology." Amer. Assoc. Petrol. Geol. Bull., vol. 87, p. 325-353, 2004.

[17]. S. Ali, V. M. Arash, K. Ya $\square$ mur and K. Y. Ay $\square$ e, "Evaluation of the Hydrocarbon Potential, Mineral Matrix effect and Gas-Oil Ratio Potential of Oil Shale from the Kabalar Formation, Göynük, Turkey." Oil Shale, vol. 32 no. 1, p. 25-41, 2015.

[18]. M. J. Hunt, Petroleum geochemistry and geology. Freeman, San Francisco, 1979.

[19]. G. P. Cooles, A. S. Mackenzie and T. M. Quigley, "Calculation of petroleum masses generated and expelled from source rocks." Org. Geochem., vol. 10, p. 235-245, 1986.

[20]. K. E. Peters and J. M. Moldowan, The Biomarker Guide: Interpreting Molecular Fossils in Petroleum and Ancient Sediments. Prentice Hall Englewood Cliff, NJ., 1993, p. 363.

[21]. E. Eseme, C. M. Agyingi and J. Foba-Tedo, "Geochemistry of brine emanations from Cretaceous strata of the Mamfe Basin, Cameroon." J. Afri. Earth Sci., 35(4), 467-476, 2002.

[22]. E. Eseme, R. Littke and C. M. Agyingi, "Geochemical characterization of a Cretaceous black shale from Mamfe Basin, Cameroon." Petrol. Geosci., vol. 12, p. 69 - 74, 2006.

[23]. L. Sengüler, T. Ayyildiz, Y. Onal, and M. Onal, "Organic Geochemical Characterization and Mineralogic Properties of Mengen Oil Shale (Lutetian), Bolu-Turkey.” Oil Shale, vol. 25 no.3, p. 359-375, 2008. 